\title{
FAKTOR-FAKTOR YANG MEMPENGARUHI LITERASI FINANSIAL MAHASISWA FAKULTAS EKONOMI DAN BISNIS UNIVERSITAS BRAWIJAYA
}

\author{
Irin Widayati \\ Pendidikan Akuntansi IKIP PGRI MADIUN \\ irin_wida@yahoo.com
}

\begin{abstract}
The purpose of this study to clarify: (1) the influence of socio-economic status of parents towards education family financial management, (2) the influence of parental socioeconomic status on cognitive aspects of financial literacy, (3) the influence of parental socioeconomic status on financial literacy aspects of attitude, (4) the effect of family financial management education to the cognitive aspects of financial literacy, (5) the effect of family financial management education for financial literacy aspect of attitude, (6) the effect of learning in higher education to cognitive aspects of financial literacy, (7) the effect of learning college for financial literacy aspect of attitude; (8) the effect of socioeconomic status of parents of student cognitive aspects of financial literacy through education family financial management; (9) the influence of socio-economic status of parents towards financial literacy aspect of student attitudes through education family financial management. Data collected using tests and questionnaires from 220 students. Data analysis techniques in this study using path analysis. The results of the study are: (1) socio-economic status of parents significant positive direct effect on education family financial management, (2) socio-economic status of parents does not directly influence the cognitive aspects of financial literacy, (3) socio-economic status of parents do not have direct the financial literacy aspect of attitude, (4) education family financial management a significant positive direct effect on the cognitive aspects of financial literacy, (5) education family financial management a significant positive direct effect on financial literacy aspect of attitude, (6) learning in higher education have direct positive significant impact on the cognitive aspects of financial literacy, (7) learning in higher education have significant positive direct effect on financial literacy aspect of attitude; (8) socio-economic status of parents significantly positive indirect effect on the cognitive aspects of financial literacy education mediated by family financial management; (9) the socioeconomic status of parents significantly positive indirect effect on the financial literacy aspect of attitude that is mediated by a family financial management education.
\end{abstract}

Keywords: parental socioeconomic status, education, family financial management, teaching in colleges, financial literacy

\section{ABSTRAK}

Tujuan penelitian ini untuk menjelaskan: (1) pengaruh status sosial ekonomi orang tua terhadap pendidikan pengelolaan keuangan keluarga; (2) pengaruh status sosial ekonomi orang tua terhadap literasi finansial aspek kognitif; (3) pengaruh status sosial ekonomi orang tua terhadap literasi finansial aspek sikap; (4) pengaruh pendidikan pengelolaan keuangan keluarga terhadap literasi finansial aspek kognitif; (5) pengaruh pendidikan pengelolaan keuangan keluarga terhadap literasi finansial aspek sikap; (6) pengaruh pembelajaran di perguruan tinggi terhadap literasi finansial aspek kognitif; (7) pengaruh pembelajaran di perguruan tinggi terhadap literasi finansial aspek sikap; (8) pengaruh status sosial ekonomi orang tua terhadap literasi finansial aspek kognitif mahasiswa melalui pendidikan pengelolaan keuangan keluarga; (9) pengaruh status sosial 
ekonomi orang tua terhadap literasi finansial aspek sikap mahasiswa melalui pendidikan pengelolaan keuangan keluarga. Data dikumpulkan dengan menggunakan tes dan angket dari 220 mahasiswa. Teknik analisis data dalam penelitian ini menggunakan analisis jalur. Hasil penelitian adalah: (1) status sosial ekonomi orang tua berpengaruh langsung positif signifikan terhadap pendidikan pengelolaan keuangan keluarga; (2) status sosial ekonomi orang tua tidak berpengaruh langsung terhadap literasi finansial aspek kognitif; (3) status sosial ekonomi orang tua tidak berpengaruh langsung terhadap literasi finansial aspek sikap; (4) pendidikan pengelolaan keuangan keluarga berpengaruh langsung positif signifikan terhadap literasi finansial aspek kognitif; (5) pendidikan pengelolaan keuangan keluarga berpengaruh langsung positif signifikan terhadap literasi finansial aspek sikap; (6) pembelajaran di perguruan tinggi berpengaruh langsung positif signifikan terhadap literasi finansial aspek kognitif; (7) pembelajaran di perguruan tinggi berpengaruh langsung positif signifikan terhadap literasi finansial aspek sikap; (8) status sosial ekonomi orang tua berpengaruh tidak langsung positif signifikan terhadap literasi finansial aspek kognitif yang dimediasi oleh pendidikan pengelolaan keuangan keluarga; (9) status sosial ekonomi orang tua berpengaruh tidak langsung positif signifikan terhadap literasi finansial aspek sikap yang dimediasi oleh pendidikan pengelolaan keuangan keluarga.

Kata kunci: status sosial ekonomi orang tua, pendidikan pengelolaan keuangan keluarga, pembelajaran di perguruan tinggi, literasi finansial

\section{PENDAHULUAN}

Salah satu kecerdasan yang harus dimiliki oleh manusia modern adalah kecerdasan finansial, yaitu kecerdasan dalam mengelola aset keuangan pribadi. Dengan menerapkan cara pengelolaan keuangan yang benar, maka seseorang diharapkan bisa mendapatkan manfaat yang maksimal dari uang yang dimilikinya. Dalam kehidupan pribadi seseorang, pada dasarnya sebuah keputusan keuangan yang diambil ada tiga: (1) berapa jumlah yang harus dikonsumsi tiap periode; (2) apakah ada kelebihan pengahsilan dan bagaimana kelebihan tersebut diinvestasikan; dan (3) bagaimana mendanai konsumsi dan investasi tersebut. Dalam rangka mencapai kesejahteraan keuangan, seseorang perlu memiliki pengetahuan, sikap, dan implementasi keuangan pribadi yang sehat. Sejauh mana pengetahuan, sikap dan implementasi seseorang dalam mengelola keuangan, dikenal dengan literasi finansial.

Mahasiswa sebagai generasi muda tidak hanya akan menghadapi kompleksitas yang semakin meningkat dalam produk-produk keuangan, jasa, dan pasar, tetapi mereka lebih cenderung harus menanggung risiko keuangan di masa depan yang lebih dari orang tua mereka (Lusardi, 2010). Mahasiswa umumnya memiliki kebebasan yang lebih besar untuk membuat keputusan pribadi dalam hal keuangan. Banyak mahasiswa belajar dari trial and error, namun hal itu belum mampu menjadikan mereka menjadi pelaku ekonomi yang cerdas dalam kehidupan saat ini. Mahasiswa dihadapkan pada permasalahan apakah mereka secara finansial sudah siap untuk hidup mandiri, dan memulai sebuah keluarga. Chen dan Volpe (1998) dalam penelitiannya menemukan bahwa mahasiswa yang memiliki tingkat literasi finansial rendah cenderung berpendapat negatif tentang keuangan dan membuat keputusan yang salah. Dengan memiliki literasi finansial, mahasiswa mampu membuat keputusan untuk kehidupan mereka dan menerima tanggung jawab atas tindakan mereka sendiri.

Pendidikan sangat berperan penting dalam pembentukan literasi finansial baik pendidikan informal di lingkungan keluarga maupun pendidikan formal di lingkungan perguruan tinggi. Di dalam lingkungan keluarga, tingkat literasi finansial ditentukan oleh 
peran orang tua dalam memberikan dukungan berupa pendidikan keuangan dalam keluarga. Melalui pendidikan keluarga, dengan cara-cara yang sederhana anak dibawa ke suatu sistem nilai atau sikap hidup yang diinginkan dan disertai teladan orang tua yang secara tidak langsung sudah membawa anak kepada pandangan dan kebiasaan tertentu. Jorgensen (2007) menyatakan "Students who reported they learned either some or a lot about managing their money from parents had higher financial knowledge, attitude, and behavior scores than students who reported learning none or not much about managing their money from their parents." Pendidikan pengelolaan keuangan di dalam keluarga dipengaruhi oleh status sosial ekonomi orang tua. Perbedaan status sosial ekonomi orang tua membawa perbedaan yang besar dalam pengasuhan anak. Anak-anak dikondisikan oleh posisi subkultur dan kelas sosial ekonomi yang pada gilirannya mempengaruhi kognisi dan perilaku mereka.

Pembelajaran di perguruan tinggi sangat berperan penting dalam proses pembentukan literasi finansial mahasiswa. Mahasiswa tinggal di lingkungan ekonomi yang beragam dan kompleks sehingga peningkatan kebutuhan pendidikan keuangan sangat diperlukan. Beberapa negara telah mengakui perlunya literasi finansial diajarkan di dalam kelas. Pembelajaran yang efektif dan efisien akan membantu mahasiswa memiliki kemampuan memahami, menilai, dan bertindak dalam kepentingan keuangan mereka. Gutter (2008) dalam penelitiannya menyatakan bahwa pendidikan keuangan berpengaruh positif signifikan terhadap pengetahuan, sikap dan perilaku keuangan. Diperkuat oleh penelitian Lutfi dan iramani (2008) yang menyatakan bahwa pendidikan manajemen keuangan secara signifikan berpengaruh terhadap literasi finansial.

\section{TELAAH LITERATUR}

\section{Literasi Finansial}

Literasi finansial berkaitan dengan kompetensi seseorang untuk mengelola keuangan. Definisi literasi finansial menurut Vitt et. al. (dalam Huston, 2010):

Personal financial literacy is the ability to read, analyze, manage and communicate about the personal financial condition that affect material well-being. It includes the ability to discern financial choices, discuss money and financial issues without (or despite) discomfort, plan for the future and respond competently to life events that affect everyday financial decisions, including events in the general economy.

Literasi finansial terjadi ketika individu memiliki sekumpulan keahlian dan kemampuan yang membuat orang tersebut mampu memanfaatkan sumber daya yang ada untuk mencapai tujuan. Huston (2010) menyatakan bahwa pengetahuan finansial merupakan dimensi yang tidak terpisahkan dari literasi finansial, namun belum dapat menggambarkan literasi finansial.

Remund (2010) menyatakan empat hal yang paling umum dalam finansial literasi adalah penganggaran, tabungan, pinjaman, dan investasi. Jumpstart Coalition membagi pengetahuan keuangan dalam topik-topik pendapatan, pengelolaan uang, tabungan dan investasi, dan pinjaman atau kredit. Peneliti mengembangkan 15 indikator melek finansial disesuaikan dengan kondisi di Indonesia yaitu: 1) mencari pilihan-pilihan dalam berkarir, 2) memahami faktor-faktor yang mempengaruhi gaji bersih, 3) mengenal sumber-sumber pendapatan, 4) menjelaskan bagaimana mencapai kesejahteraan dan memenuhi tujuan keuangan, 5) memahami anggaran menabung, 6) memahami asuransi, 7) menganalisis risiko, pengembalian, dan likuiditas, 8) mengevaluasi alternatif-alternatif investasi, 9) menganalisis pengaruh pajak dan inflasi terhadap hasil investasi, 10) menganalisis keuntungan dan kerugian berhutang, 11) menjelaskan tujuan dari rekam jejak kredit dan mengenal hak-hak debitur, 12) mendeskripsikan cara-cara untuk menghindari atau memperbaiki masalah hutang, 13) mengetahui hukum dasar perlindungan konsumen dalam 
kredit dan hutang, 14) mampu membuat pencatatan keuangan, dan 15) memahami laporan neraca, laba rugi, dan arus kas.

Literasi finansial tidak hanya melibatkan pengetahuan dan kemampuan untuk menangani masalah keuangan, tetapi juga atribut nonkognitif (PISA, 2010). Sikap merupakan unsur penting dalam literasi finansial. Sikap keuangan diartikan sebagai karakteristik psikologis seseorang yang berkaitan dengan masalah keuangan pribadi (Gutter, 2008). Sikap keuangan seperti sikap terbuka terhadap informasi, menilai pentingnya mengelola keuangan, tidak impulsif dalam konsumsi, orientasi ke masa depan, dan tanggung jawab. MCEETYA (2009) menjelaskan "Responsibility is appropriate consumer and financial decisions that display care for self, others, the community and the environment".

\section{Status Sosial Ekonomi Orang Tua}

Latar belakang orang tua, pekerjaan orang tua, jabatan sosial orang tua dapat mempengaruhi sikap seseorang dalam melakukan kegiatan belanja, menabung, investasi, kredit, penganggaran, dan pengelolaan keuangan. Menurut Ahmadi (2007: 229) status sosial ekonomi orang tua mempunyai pengaruh terhadap tingkah laku dan pengalaman anak-anaknya. Perbedaan tingkat status sosial ekonomi akan berdampak pada munculnya perbedaan persepsi atas suatu obyek fisik atau obyek perilaku, yang pada akhirnya membentuk sikap yang berbeda pula. Persepsi positif terhadap karakteristik atau sifat obyek akan membentuk sikap positif pula. Hasil penelitian Lusardi et. al., (2010) "parent education, parental wealth, and sophistication of the family finances significantly influence the financial literacy of children." Fowdar (2007) dalam penelitiannya menyatakan bahwa tingkat literasi seseorang dipengaruhi oleh tingkat pekerjaan orang tua. Selanjutnya penelitian Gutter (2008) menyatakan bahwa mahasiswa yang mempunyai status sosial ekonomi yang tinggi juga mempunyai tingkat pengetahuan, sikap, dan perilaku keuangan yang tinggi.

\section{Pendidikan Pengelolaan Keuangan Keluarga}

Keluarga merupakan tempat yang paling dominan dalam proses sosialisasi anak tentang masalah keuangan. Melalui pendidikan keluarga, dengan cara-cara yang sederhana anak dibawa ke suatu sistem nilai atau sikap hidup yang diinginkan dan disertai teladan orang tua yang secara tidak langsung sudah membawa anak kepada pandangan dan kebiasaan tertentu. Orang tua mengajar bagaimana anaknya bertindak dengan mengandalkan nilai-nilai, keyakinan, dan pengetahuan dalam segala bidang termasuk yang berhubungan dengan keuangan.

Pendidikan pengelolaan keuangan di lingkungan keluarga dititik beratkan pada pemahaman tentang nilai uang dan penanaman sikap serta perilaku anak untuk dapat mengatur pemanfaatan uang. Seorang ahli kecerdasan finansial anak, Cathy Malmrose, menyatakan bahwa untuk memiliki keterampilan mengelola keuangan dengan baik, paling tidak anak harus dilatih dalam hal menabung, melakukan pembayaran secara mandiri atas kebutuhan-kebutuhan tambahan mereka, mengelola uang saku, melakukan pekerjaanpekerjaan rumah tertentu untuk mendapatkan uang saku tambahan, mencari pekerjaan ringan di luar rumah, berderma dan berinvestasi (Owen, 2003: x). Dalam penelitian Jorgensen (2007) ditemukan "students who were financially influenced by their parents had higher financial knowledge, attitude, and behavior scores." Cude et. al. (2006) menyatakan bahwa orang tua memainkan peranan yang sangat penting dalam proses sosialisasi keuangan anak-anak mereka.

\section{Pembelajaran Keuangan di Perguruan Tinggi}


Pembelajaran hakikatnya adalah usaha sadar guru untuk membelajarkan siswanya (mengarahkan interaksi siswa dengan sumber belajar lainnya) dalam rangka mencapai tujuan yang diharapkan (Trianto, 2009: 17). Pembelajaran di perguruan tinggi sangat berperan penting dalam proses pembentukan literasi finansial mahasiswa. Melalui kombinasi berbagai metode pengajaran, media dan sumber belajar yang direncanakan dengan baik dan sesuai dengan kompetensi, diharapkan mampu memberikan bekal kepada mahasiswa untuk memiliki kecakapan di bidang keuangan, sehingga mahasiswa menjadi siap dan mampu menghadapi kehidupan mereka saat ini maupun masa depan yang semakin kompleks (Lutfi dan Iramani, 2008. Adapun penelitian terkait yaitu hasil penelitian Jhonson (2007) menyatakan bahwa pendidikan keuangan memiliki peran yang sangat penting bagi siswa untuk memiliki kemampuan memahami, menilai, dan bertindak dalam kepentingan keuangan mereka. Selanjutnya Gutter (2008) dalam penelitiannya menyatakan bahwa pendidikan keuangan berpengaruh positif signifikan terhadap pengetahuan dan sikap keuangan. Diperkuat oleh penelitian Lutfi dan Iramani (2008) yang menyatakan bahwa pendidikan manajemen keuangan secara signifikan berpengaruh terhadap literasi finansial.

\section{Pengembangan Hipotesis}

Hubungan antar variabel di atas dinyatakan dalam Gambar 2.1 berikut:

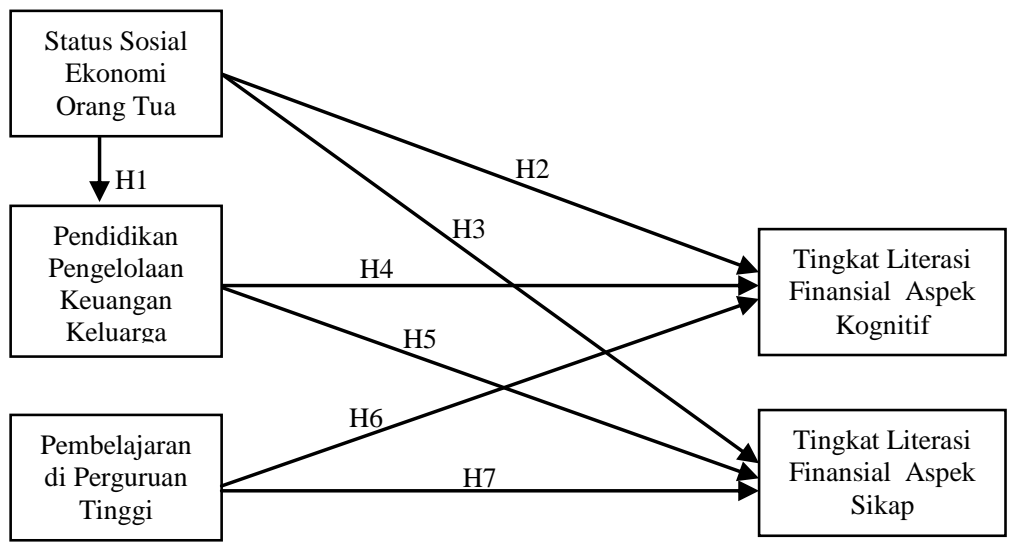

Gambar 1. Hubungan antar variabel

\section{METODE PENELITIAN}

Populasi dan sampel penelitian ini adalah mahasiswa Fakultas Ekonomi dan Bisnis Universitas Brawijaya yang terdiri atas mahasiswa jurusan ekonomi pembangunan, akuntansi, dan manajemen. Jumlah anggota sampel 220 mahasiswa yang ditentukan secara proportionate random sampling. Data dikumpulkan dengan menggunakan tes dan angket. Tes digunakan untuk memperoleh data tentang literasi finansial aspek kognitif melalui soal obyektif yang terdiri atas 25 soal pilihan ganda. Skor maksimum pengetahuan mahasiswa mengenai dasar-dasar keuangan adalah 100 dan skor minimum adalah 0 (nol). Angket digunakan untuk memperoleh data tentang literasi finansial aspek sikap, status sosial ekonomi orang tua, pendidikan pengelolaan keuangan keluarga, dan pembelajaran di perguruan tinggi. Angket yang digunakan berupa angket dengan pertanyaan yang bersifat tertutup.Teknik analisis data yang digunakan adalah analisis jalur dan analisis regresi dengan uji selisih mutlak dengan bantuan SPSS versi 16.0 for window. Spesifikasi model analisis jalur dinyatakan dalam Gambar 2 berikut ini: 


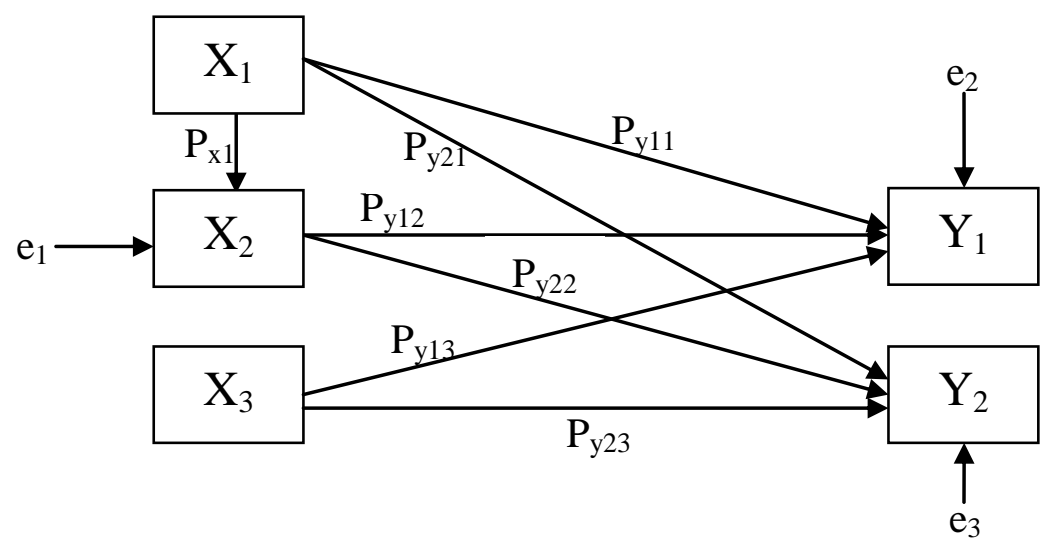

Gambar 2. Model Informal Variabel analisis jalur

Berdasarkan model di atas, disusun model formal dalam persamaan jalur sebagai berikut: $\mathrm{X}_{2}=\mathrm{P}_{21} \mathrm{X}_{1}+\mathrm{P}_{2 \mathrm{R} 1} \mathrm{R}_{1}$

$$
\begin{aligned}
& Y_{1}=P_{y 11} X_{1}+P_{y 12} X_{2}+P_{y 13} X_{3}+P_{y 1 R 1} R_{2} \\
& Y_{2}=P_{y 21} X_{1}+P_{y 22} X_{2}+P_{y 33} X_{3}+P_{y 2 R 1} R_{3}
\end{aligned}
$$

Menurut Ghozali, 2007: 175 Koefisien jalur residual dihitung secara manual dengan rumus:

Blok 1: $\mathrm{P}_{2 \mathrm{R} 1}=\sqrt{1-R^{2} B L O K 1}$
Blok 2 $\mathrm{P}_{\mathrm{y} 1 \mathrm{R} 2}=\sqrt{1-R^{2} B L O K 2}$
Blok $3: \mathrm{P}_{\mathrm{y} 2 \mathrm{R} 2}=\sqrt{1-R^{2} B L O K 3}$

\section{Paparan Hasil Penelitian}

\section{HASIL DAN PEMBAHASAN}

Gambaran hasil penelitian pada masing-masing variabel dapat dilihat pada tabel 1 sebagai berikut:

\begin{tabular}{|c|c|c|}
\hline Variabel & Kategori & Keterangan \\
\hline Finlit Aspek Kognitif & Cukup & $\begin{array}{l}40,91 \% \text { mahasiswa memiliki tingkat literasi finansial aspek } \\
\text { kognitif yang tinggi }\end{array}$ \\
\hline Finlit Aspek Sikap & Tinggi & $\begin{array}{l}63,18 \% \text { mahasiswa memiliki tingkat literasi finansial aspek } \\
\text { sikap yang tinggi }\end{array}$ \\
\hline SSE Orang Tua & Cukup & 43,63\% mahasiswa memiliki SSE cukup tinggi \\
\hline $\begin{array}{l}\text { Pendidikan Pengelolaan } \\
\text { Keuangan Keluarga }\end{array}$ & Tinggi & $\begin{array}{l}52,73 \% \text { mahasiswa menyatakan pendidikan pengelolaan } \\
\text { keuangan keluarganya tinggi dan sangat tinggi }\end{array}$ \\
\hline $\begin{array}{l}\text { Pembelajaran } \\
\text { Manajemen Keuangan }\end{array}$ & Cukup & $\begin{array}{l}57,27 \% \text { mahasiswa menyatakan pembelajaran manajemen } \\
\text { keuangan cukup baik, kurang baik dan sangat kurang }\end{array}$ \\
\hline $\begin{array}{l}\text { Pembelajaran Hukum } \\
\text { Komersial }\end{array}$ & Cukup & $\begin{array}{l}56,82 \% \text { mahasiswa menyatakan pembelajaran hukum } \\
\text { komersialcukup baik, kurang baik dan sangat kurang }\end{array}$ \\
\hline $\begin{array}{l}\text { Pembelajaran } \\
\text { Pengantar Akuntansi }\end{array}$ & Baik & $\begin{array}{l}\text { 57,28\% mahasiswa menyatakan pembelajaran pengantar } \\
\text { akuntansi baik dan sangat baik }\end{array}$ \\
\hline
\end{tabular}

Tabel 1. Gambaran masing-masing variabel

Pengaruh status sosial ekonomi orang tua terhadap pendidikan pengelolaan keuangan keluarga

Status sosial ekonomi orang tua mempunyai pengaruh langsung positif signifikan terhadap pendidikan pengelolaan keuangan keluarga. Hal ini dilihat dari besaran probabilitas (sig.) $=0,000<0,050(\alpha)$ dan nilai koefisien beta terstandarisasi sebesar 0,514 dengan nilai $t_{\text {hitung }}$ sebesar 8,874. Aspek-aspek yang mempengaruhi pendidikan 
pengelolaan keuangan keluarga berdasarkan pada status sosial ekonomi orang tua meliputi tingkat pendidikan orang tua, jenis pekerjaan orang tua, tingkat pendapatan orang tua, jabatan sosial orang tua dan uang saku mahasiswa. Literatur juga menunjukkan bahwa tingkat pendidikan berpengaruh terhadap pengetahuan orang tua, keyakinan, nilai, dan tujuan tentang pengasuhan (Henslin, 2006).

Menurut Wahyono (2001) orang tua yang memiliki status sosial lebih tinggi, cenderung memiliki wawasan yang lebih luas, lebih mampu meraih pendapatan yang lebih besar, dan lebih mampu untuk berinteraksi dengan lingkungan sosialnya dibandingkan dengan seseorang yang berstatus sosial ekonomi rendah.

\section{Pengaruh status sosial ekonomi orang tua terhadap literasi finansial aspek kognitif}

Status sosial ekonomi orang tua tidak mempunyai pengaruh langsung positif signifikan terhadap literasi finansial aspek kognitif. Hal ini dilihat dari besaran probabilitas (sig.) $=0,074>0,050(\alpha)$ dan nilai koefisien beta terstandarisasi sebesar 0,121 dengan nilai $t_{\text {hitung }}$ sebesar 1,792. Beberapa penelitian menemukan hasil yang berbeda-beda mengenai pengaruh status sosial akonomi orang tua terhadap literasi finansial. Hasil penelitian yang dilakukan oleh Lusardi et al. (2010) dan Fowdar (2007) menemukan bahwa status sosial ekonomi orang tua berpengaruh terhadap tingkat literasi finansial anak. Penelitian Haryono (2008) menyatakan bahwa ada pengaruh negatif signifikan dari status sosial ekonomi orang tua terhadap economic literacy siswa dan diindikasikan bahwa pengaruh status sosial ekonomi orang tua terhadap economic literacy kurang konsisten.

Secara teori, orang tua yang memiliki pendapatan yang tinggi dapat memfasilitasi anaknya untuk menabung, dan sebagainya. Secara empiris ternyata ditemukan bahwa status sosial ekonomi orang tua tidak berpengaruh terhadap literasi finansial aspek kognitif. Tanpa pengarahan dan bimbingan dari orang tua, status status sosial ekonomi tidak mempengaruhi tingkat literasi finansial mahasiswa secara kognitif. Pengalaman dalam kehidupan ekonomi sehari-hari khususnya dalam hal keuangan tidak memberikan makna yang berarti bagi pemahaman dasar mahasiswa tentang keuangan, sehingga pengalaman yang dialami mahasiswa tidak memberikan kontribusi sebuah pengetahuan yang berarti bagi mahasiswa.

\section{Pengaruh status sosial ekonomi orang tua terhadap literasi finansial aspek sikap}

Status sosial ekonomi orang tua tidak mempunyai pengaruh langsung positif signifikan terhadap literasi finansial aspek sikap. Hal ini dilihat dari besaran probabilitas (sig.) $=0,878>0,050(\alpha)$ dan nilai koefisien beta terstandarisasi sebesar 0,011 dengan nilai $t_{\text {hitung }}$ sebesar 0,153 . Hasil penelitian tidak sejalan dengan penelitian yang dilakukan oleh Lusardi et al. (2010) dan Fowdar (2007) yang menemukan bahwa status sosial ekonomi orang tua berpengaruh terhadap tingkat literasi finansial anak. Demikian juga penelitian yang dilakukan Lestari (2010) yang menyatakan bahwa status sosial ekonomi berpengaruh positif terhadap sikap rasional siswa dalam ekonomi. Pengembangan literasi finansial sangat terkait dengan aktivitas yang dilakukan seseorang yang berhubungan dengan penggunaan uang. Ahmadi (2007) mengungkapkan bahwa status sosial ekonomi orang tua mempunyai pengaruh terhadap tingkah laku dan pengalaman anak-anaknya.

Namun hasil penelitian ini tidak mendukung teori tersebut dan hal ini dikarenakan berbagai hal. Seperti pada penjelasan sebelumnya, pengalaman dalam kehidupan ekonomi sehari-hari khususnya dalam hal keuangan tidak memberikan makna yang berarti bagi perubahan sikap mahasiswa tentang keuangan. Mahasiswa dengan status sosial ekonomi orang tua yang tinggi, dapat memiliki sikap bahwa mereka dapat memperoleh uang dengan mudah dan mereka dapat memiliki apapun yang mereka inginkan. Mahasiswa yang memiliki status sosial ekonomi rendah mampu menerapkan hidup hemat dan lebih berhatihati dalam masalah keuangan. 


\section{Pengaruh pendidikan pengelolaan keuangan keluarga terhadap literasi finansial aspek kognitif}

Pendidikan pengelolaan keuangan keluarga mempunyai pengaruh langsung positif signifikan terhadap literasi finansial aspek kognitif. Hal ini dilihat dari besaran probabilitas (sig.) $=0,003<0,050(\alpha)$ dan nilai koefisien beta terstandarisasi sebesar 0,210 dengan nilai $t_{\text {hitung }}$ sebesar 2,990. Temuan ini sejalan dengan hasil penelitian sebelumnya yang dilakukan oleh Jorgensen (2007) yang menyatakan bahwa siswa yang belajar banyak tentang mengelola keuangan pada orang tuanya memiliki pengetahuan keuangan yang lebih tinggi daripada siswa yang tidak belajar tentang mengelola keuangan pada orang tuanya. Penelitian yang dilakukan oleh Cude et. al. (2006) menyatakan bahwa orang tua memainkan peranan yang sangat penting dalam proses sosialisasi keuangan anak-anak mereka. Selain itu, bahwa diskusi secara langsung dengan keluarga mengenai pengelolaan uang akan meningkatkan pengetahuan dan pembentukan sikap, nilai dan perilaku anakanak (Jorgensen, 2007).

\section{Pengaruh pendidikan pengelolaan keuangan keluarga terhadap literasi finansial aspek sikap}

Pendidikan pengelolaan keuangan keluarga mempunyai pengaruh langsung positif signifikan terhadap literasi finansial aspek sikap. Hal ini dilihat dari besaran probabilitas (sig.) $=0,000<0,050(\alpha)$ dan nilai koefisien beta terstandarisasi sebesar 0,338 dengan nilai $t_{\text {hitung }}$ sebesar 4,500 . Temuan penelitian ini sejalan dengan penelitian yang dilakukan oleh jorgensen (2007) yang menyatakan bahwa siswa yang belajar banyak tentang mengelola keuangan pada orang tuanya memiliki sikap keuangan yang lebih tinggi daripada siswa yang tidak belajar tentang mengelola keuangan pada orang tuanya. Penelitian Wahyono (2001) menemukan bahwa pendidikan ekonomi dalam lingkungan keluarga berpengaruh terhadap penanaman sikap-sikap positif dalam lingkungan keluarga.

Jika dibandingkan dengan pengaruh pendidikan pengelolaan keuangan keluarga terhadap literasi finansial aspek kognitif, pengaruh pendidikan pengelolaan keuangan keluarga terhadap literasi finansial aspek sikap lebih tinggi. Dilihat dari koefisien beta terstandarisasi untuk pendidikan pengelolaan keuangan keluarga terhadap literasi finansial aspek kognitif sebesar 0,210. Nilai koefisien beta terstandarisasi untuk pendidikan pengelolaan keuangan keluarga terhadap literasi finansial aspek sikap sebesar 0,338.

Pengaruh pembelajaran di perguruan tinggi terhadap literasi finansial aspek kognitif

Pembelajaran di perguruan tinggi mempunyai pengaruh langsung positif signifikan terhadap literasi finansial aspek kognitif. Hal ini dilihat dari besaran probabilitas (sig.) = $0,000<0,050(\alpha)$ dan nilai koefisien beta terstandarisasi sebesar 0,364 dengan nilai $t_{\text {hitung }}$ sebesar 5,977. Temuan ini searah dengan hasil-hasil penelitian terdahulu yang menyatakan bahwa pembelajaran keuangan berpengaruh positif terhadap pengetahuan keuangan mahasiswa. Seperti diungkap oleh Lutfi \& Iramani (2008) yang meneliti literasi finansial mahasiswa STIE Perbanas Surabaya, menyatakan bahwa pendidikan manajemen keuangan secara signifikan berpengaruh terhadap literasi finansial mahasiswa. Penelitian Gutter (2008) menemukan yang sama bahwa pendidikan keuangan berpengaruh positif terhadap pengetahuan keuangan. Dalam penelitian ini proses pembelajaran manajemen keuangan dan hukum komersial dinilai cukup baik, dan proses pembelajaran pengantar akuntansi dinilai baik. Maka dapat dipahami jika dengan mendapatkan pembelajaran manajemen keuangan, hukum komersial, dan pengantar akuntansi, dapat meningkatkan literasi finansial mahasiswa aspek kognitif. 


\section{Pengaruh pembelajaran di perguruan tinggi terhadap literasi finansial aspek sikap}

Pembelajaran di perguruan tinggi mempunyai pengaruh langsung positif signifikan terhadap literasi finansial aspek sikap. Hal ini dilihat dari besaran probabilitas (sig.) = $0,020<0,050(\alpha)$ dan nilai koefisien beta terstandarisasi sebesar 0,154 dengan nilai $t_{\text {hitung }}$ sebesar 2,348. Temuan ini searah dengan penelitian Haryono (2008) yang menyatakan bahwa kualitas proses pembelajaran di sekolah berpengaruh positif terhadap rasionalitas ekonomi dan moralitas ekonomi siswa. Demikian juga penelitian yang dilakukan oleh Gutter (2008) menyatakan bahwa pendidikan keuangan berpengaruh positif signifikan terhadap sikap keuangan. Huddleston et al. dalam Gutter (2008) juga menyatakan bahwa program keuangan pribadi memiliki dampak positif pada tingkat literasi finansial dan tingkat self efficacy.

Dalam penelitian ini, pengaruh pembelajaran di perguruan tinggi terhadap literasi finansial aspek sikap lebih rendah dibandingkan pengaruh pembelajaran di perguruan tinggi terhadap literasi finansial kognitif. Hal ini dapat diartikan bahwa di Fakultas Ekonomi dan Bisnis Universitas Brawijaya, pembelajaran terkait dengan keuangan yaitu pembelajaran manajemen keuangan, hukum komersial, dan pengantar akuntansi masih lebih mengarah pada aspek kognitif dan belum banyak mengarah ke aspek sikap.

Pengaruh status sosial ekonomi orang tua terhadap literasi finansial aspek kognitif mahasiswa melalui pendidikan pengelolaan keuangan keluarga

Status sosial ekonomi orang tua berpengaruh secara tidak langsung positif signifikan terhadap literasi finansial aspek kognitif melalui pendidikan pengelolaan keuangan keluarga. Hal ini dilihat dari besarnya pengaruh tidak langsung sebesar 0,108. Pendidikan pengelolaan keuangan keluarga bertindak sebagai mediator. Penelitian ini membuktikan bahwa status sosial ekonomi orang tua terbukti berpengaruh terhadap literasi finansial aspek kognitif bila variabel tersebut dikaitkan dengan pendidikan pengelolaan keuangan keluarga. Dengan semakin tinggi status sosial ekonomi orang tua, makin besar kesempatan mahasiswa untuk memperoleh pengalaman belajar dalam kehidupan yang berkaitan dengan aspek keuangan (Ahmadi, 2007). Dengan adanya pendidikan pengelolaan keuangan keluarga, pengalaman-pengalaman siswa menjadi bermakna sehingga berkontribusi dalam meningkatkan pengetahuan dasar keuangan mahasiswa.

\section{Pengaruh status sosial ekonomi orang tua terhadap literasi finansial aspek sikap mahasiswa melalui pendidikan pengelolaan keuangan keluarga}

Status sosial ekonomi orang tua berpengaruh secara tidak langsung positif signifikan terhadap literasi finansial aspek sikap melalui pendidikan pengelolaan keuangan keluarga. Hal ini dilihat dari besarnya pengaruh tidak langsung sebesar 0,174. Pendidikan pengelolaan keuangan keluarga bertindak sebagai mediator. Penelitian ini membuktikan bahwa status sosial ekonomi orang tua terbukti berpengaruh terhadap literasi finansial aspek sikap bila variabel tersebut dikaitkan dengan pendidikan pengelolaan keuangan keluarga. Dengan adanya penanaman sikap, keyakinan dan nilai-nilai pada anak, maka akan mempengaruhi sikap anak terhadap uang. Misalnya mahasiswa yang memiliki status sosial ekonomi orang tua yang tinggi tidak akan bersikap boros dan mempunyai penilaian bahwa kesejahteraan keuangan itu sangat penting.

\section{KESIMPULAN}

Berdasarkan hasil analisis data, diperoleh kesimpulan: (1) status sosial ekonomi orang tua berpengaruh langsung positif signifikan terhadap pendidikan pengelolaan keuangan keluarga; (2) status sosial ekonomi orang tua tidak berpengaruh langsung terhadap literasi finansial aspek kognitif; (3) status sosial ekonomi orang tua tidak berpengaruh langsung terhadap literasi finansial aspek sikap; (4) pendidikan pengelolaan 
keuangan keluarga berpengaruh langsung positif signifikan terhadap literasi finansial aspek kognitif; (5) pendidikan pengelolaan keuangan keluarga berpengaruh langsung positif signifikan terhadap literasi finansial aspek sikap; (6) pembelajaran di perguruan tinggi berpengaruh langsung positif signifikan terhadap literasi finansial aspek kognitif; (7) pembelajaran di perguruan tinggi berpengaruh langsung positif signifikan terhadap literasi finansial aspek sikap; (8) status sosial ekonomi orang tua berpengaruh tidak langsung positif signifikan terhadap literasi finansial aspek kognitif yang dimediasi oleh pendidikan pengelolaan keuangan keluarga; (9) status sosial ekonomi orang tua berpengaruh tidak langsung positif signifikan terhadap literasi finansial aspek sikap yang dimediasi oleh pendidikan pengelolaan keuangan keluarga.

Merujuk pada hasil penelitian dapat disarankan: (1) hendaknya orang tua meningkatkan pendidikan keuangan dalam keluarga dan harus menggunakan setiap kesempatan untuk mendidik tentang keuangan dan menanamkan sikap keuangan yang baik pada anak; (2) dalam proses pembelajaran di perguruan tinggi, dosen harus lebih meningkatan keterlibatan mahasiswa pada proses perencanaan pembelajaran di awal semester; (3) peneliti berikutnya untuk mengkaji lebih lanjut tentang pendidikan dalam keluarga dan pendidikan di sekolah.

\section{DAFTAR PUSTAKA}

Ahmadi, A. 1997. Ilmu Sosial dasar. Jakarta: Rineka Cipta.

Ahmadi, A. 2007. Psikologi Sosial. Jakarta: Rineka Cipta.

Chen, H. \& Volpe, R. P. 1998. An Analysis of Personal Financial Literacy Among College Students. Financial services review 7(2): 107-128.

Cude, et al. 2006. Collage Student and Financial Literacy: What They Know and What We Need to Learn. Eastern Family Economic and Resource Managemen Association.

Djemari M. 2004. Pedoman Khusus Pengembangan Instrumen dan Penilaian Ranah Afektif. Jakarta: Departemen Pendidikan nasional.

Fowdar. 2007. Financial Literacy: Evidence from Mauritius. Mauritius Research Council. Gutter, et al. 2008. Financial Management Practices of College Student from States with varying Financial Education Mandates.

Haryono, A. 2008. Pengaruh Sistem Pembelajaran dan Status Soisal Ekonomi Terhadap Economic Literacy Siswa SMA di Kota Malang. Disertasi tidak diterbitkan. Malang: PPs UM.

Huston, S.J. 2010. Measuring financial literacy. Journal of Consumer Affairs Volume 44 Issue 2.

Jhonson, E \& Margaret S.S. 2007. From Financial Literacy to Financial Capability Among The Young. Journal of Sociology and Social Welfare, 34, 119-146.

Jorgensen, B.L. 2007. Financial Literacy of College Student: Parental and Peer Influences. Thesis Master of Sains in Human Development. Virginia. 
Khrisna dkk. 2010. Analisis Tingkat Literasi Keuangan di Kalangan Mahasiswa dan Faktor-faktor yang Mempengaruhinya. Proceedings of The $4^{\text {th }}$ International Conference on Theacer Education; Joint Conference UPI \& UPSI. Bandung 8-10 Nopember 2010.

Lusardi et al. 2010. Financial Literacy Among The Young. Journal of Consumer Affairs Volume 44 Issue 2.

Lutfi \& Iramani. 2008. Financial Literacy Among University Student and Its Implications to The Teaching Method. Jurnal Ekonomi Bisnis dan Akuntansi Ventura Volume 11 no. 3.

Mandell, L. 2009. The Financial Literacy of Young American Adult: Result of the 2008 National Jump\$tart Coalition Survey of High School Senior and College Student. Washington, D.C: Jump\$tart Coalition.

MCEETYA (2009). National Consumer and Financial Literacy Framework (revised 2009). Australia.

Owen, D. 2003. Melejitkan kecerdasan Finansial Anak. Terjemahan Lovely. Bandung: Kaifa.

Paula, M C. 2010. Learning Financial Literacy in the Family. Thesis, San Jose state University.

PISA 2012 Financial Literacy Framework, 2010. Australia.

Purwanto, N. 2007. Ilmu Pendidikan Teoritis dan Praktis. Bandung: Remaja Rosda.

Remund, D L. 2010. Financial literacy explicated: the case for a clearer definition in an increasingly complex economy. Journal of Consumer Affairs Volume 44 Issue 2.

Riduwan, dan Engkos A.K. 2011. Cara Menggunakan dan memakai Path Analysis. Bandung: Alfabeta.

Trianto. 2009. Mendesain Model Pembelajaran Inovatif progresif. Jakarta: Kencana Prenada Media Grup.

Wahyono, H. 2001. Pengaruh Perilaku Ekonomi Kepala Keluarga terhadap Intensitas Pendidikan Ekonomi di Lingkungan Keluarga. Disertasi tidak diterbitkan. Malang: PPs UM. 